\title{
Unsur[e] Kaligrafi:
}

\section{On Aceh, Islamic Art, and the Terrain of Indonesian Multiculturalism}

\author{
Kenneth M. George
}

(University of Wisconsin-Madison)

\begin{abstract}
Abstrak
Tulisan ini melukiskan beberapa kecemasan yang menimpa pelukis Aceh, A.D. Pirous dan publik yang dibayangkannya, menjelang pameran besar-yang dimaksudkan sebagai sebuah retrospeksi_pada bulan Maret 2002, di Galeri Nasional, Jakarta. Kecemasan ini berakar dalam beragam bahasa, ortografi dan wacana yang belum baku. Keadaan 'goyah' ini tampak ketika 'Kesenian Islam Indonesia Kontemporer' dipertunjukkan, dipromosikan, dan didiskusikan secara publik. Ini semua berpuncak pada dorongan akan sensor terhadap diri sendiri dan pada berbagai perubahan yang dilakukan pada menit terakhir pada lukisanlukisan, katalog, dan kaos oblong untuk promosi, dan pada catatan-catatan etnografis yang disusun penulis, tentang karier pelukis. Jelas bahwa perilaku seperti ini merupakan bahagian budaya politik yang memungkinkan bertemunya Islam, Indonesia, Arab, Aceh dan seni itu sendiri dalam publik kesenian Islam kontemporer di Jakarta, dan sekaligus juga menjadi respons terhadap negara dan terhadap kekerasan gerakan separatis di Aceh. Dalam semua ini akan tampak jangkauan global dari kebudayaan visual Islam dan sirkulasinya dalam dan melalui bahasa publik negara Indonesia.
\end{abstract}

\section{Introductory remarks}

The title of my paper 'Unsur[e] Kaligrafi' came to me one evening as I was helping my friend, painter Abdul Djalil Pirous, examine draft materials for the Indonesian-language catalogue that was being prepared for his major career retrospective show in Jakarta last March. Proofreading a passage about the Arab calligraphy that is so prominent in his artwork, Pirous came across a typographic error that read 'u-n-s-u-r-e k-a-l-i-g-r-a-f-i.' He crossed out the letter ' $e$ ' so that the phrase read, in good standard Indonesian, unsur kaligrafi (English: 'calligraphic elements'). The moment I saw his editorial mark, I let out a laugh and served up a bilingual pun: 'Pirous, are you sure kata-kata ini mesti dibaca unsur kaligrafi atau unsure calligraphy?' He broke into a bright, knowing grin and came right back at me, 'I am sure it is unsur.'

The transcultural word-play between us turned on the hybrid discourse of Indonesian Islamic aesthetics, and in particular, a painterly metalanguage that draws from Indonesian, Arabic, English, Dutch, and dozens of regional languages such as Acehnese and Javanese. That discourse - fraught with ironies, puns, blasphemies, unruly codeswitchings, and conflicts over standards - comes down to us through an un- 
settled history of cultural encounter. I say "unsettled" in that the history of cultural and political claims regarding Arab and Qur'anic orthography, language, and philology remains an ongoing and contested resource within Indonesia's diverse Muslim community. In my talk today, I will tell a story about some of the anxieties that consumed Pirous and his imagined public on the eve of his major retrospective show at Jakarta's prestigious Galeri Nasional. These anxieties had to do with some 'unsure calligraphy' and culminated in acts of self-censorship, gestures that are necessarily part of the complex cultural politics that shape the confluence of 'Islam', 'Indonesia', 'Aceh', 'Arab' and 'art' in Jakarta's contemporary Muslim art public. In them we may find lessons not only about the globalized reach of Islamic visual culture and but also about prospects for a multicultural Indonesian state. In particular, I'll emphasize some of the constraints religion and nation bring to bear on a multicultural public, and call attention to the cultural politics of ambiguity in a multicultural art public.

\section{The terrain of Indonesian multiculturalism}

I'd like to begin my discussion by emphasizing the deeply political nature of Indonesian multiculturalism. Contemporary multiculturalisms, no matter where we find them, and despite their varied histories and trajectories, place collectivities and communities into confrontation with the nation-state. In many ways, multiculturalist aspirations traffic in the same notions of difference and identity as the cultural nationalisms that fueled anti-colonial struggle and the emergent nation-building projects of the postcolonial era. Such aspirations may be reckoned as a response to the perceived failings of the nation-state, especially where communities and collectivities feel the nation-state is obliged to protect or advance their interests (e.g., adat, or shari'a), and guarantee their participation in a socially, politically, and economically just public sphere or civil society. Those same aspirations might also come in response to perceived threats and predations of the nation-state (as in Aceh), or to intolerable levels of discrimination. As for the nation-state, it might commit itself to a politics of recognition and seek positive engagement with these communities and collectivities; it may abstain in part or full; or it may resort to violent suppression. As Partha Chatterjee has explained,

'The modern [postcolonial] state, embedded as it is within the universal narrative of capital, cannot recognize within its jurisdiction any form of community except the single, determinate, demographically enumerable form of the nation. It must therefore subjugate, if necessary by the use of state violence, all such aspirations of community identity'. (1993:238)

The nation-state is inevitably fearful of any cultural nationalisms from below, and promoting multiculturalism always runs the risk of spawning cultural nationalist yearnings and separatist movements. For this reason, the state assumes a watchfulness, even as it may lead a search for the cultural resources that will allow people in different communities to live and prosper together in an encompassing polity, or promote the cultural distinctions needed for participation in the global culture market (tourism, spectacle, arts, etc.).

Proponents of multiculturalism seldom see cultural difference as an end in itself (Turner 1993), but as a resource to mobilize solidarities and support in pursuit of social justice, or as an asset in identity politics. Mobilizations under the banner of cultural difference of course imply a degree of reflexivity on the part of people and institutions. For individuals and groups, a cultural identity is conjured and incorporated in the reflexive project of finding a self within the ongoing flow of community his- 
tory and tradition. Institutions no less than individuals also must see 'culture' as a basis for creating political, social, and existential realities. These projects of reflexivity rely crucially on public discussion, and indeed, multiculturalism is aimed primarily at transformations of the public sphere and secondarily at corresponding changes in experiential life-worlds. A danger, here, of course, are essentialist notions of culture that exclude or put a check to hybridity and difference within the community or collectivity, especially intracultural differences grounded in gender, religion, or kinship. Replacing the national community — which tries to maintain a monopoly over ethical and political pronouncements - with a cultural or ethnic one deemed to be more organic or authentic is thus no safeguard against tyrannies or authoritarian rule. It is inevitable then, that multiculturalist projects come to terms with what Veena Das calls the 'double life of culture':

its potential to give radical recognition to the humanity of its subjects as well as its potential to keep the individual within such tightly defined bounds that the capacity to experiment with selfhood - which is also a mark of humanity—may be jeopardized. (1995:91)

In short, multiculturalist projects are always at risk of losing their progressive potential and becoming regressive, primordialist movements that prevent human subjects from living at or beyond the margins of their cultural traditions, or from escaping subjugation at the hands of dominant intracultural groups and factions.

Aspirations for an Indonesian multicultural society and an Indonesian multicultural public sphere of course remain tethered to the idea of an Indonesian nation-state. Many Indonesians undoubtedly look to multiculturalism as a means of bringing greater inclusiveness in judicial and bureaucratic structures, in the writing of law, and in the very way the nation is imagined. We might call them 'multicultural nationalists'. Writing about the progressive potential of cultural nationalism and cultural nationalists, John Hutchinson (1994:123) argues that it is intellectuals, writers, and artists who are at the vanguard of articulating nationalist ideas, and goes so far as to say that the artist is 'the paradigmatic figure of the national community.' I see no reason why intellectuals, writers, or artists - like my friend Pirous — might not also be at the vanguard of multicultural nationalism. If this is so, yet another of Hutchinson's observations interests me here: Reformist and modernizing dimensions so crucial to progressive cultural nationalism, he says, emerge 'in conjunction with a trans-national secular culture that perceives (the world) in polycentric terms' (Hutchinson 1994:127). Is this true of Indonesia's multicultural nationalism as well? Let us turn to Pirous and his work for a provisional answer.

\section{A. D. Pirous: the multicultural nationalist}

Pirous was born in Meulaboh, Aceh, in 1932. Yet his Acehnese cultural heritage is one that he has had to self-consciously reclaim and reshape through much of his professional life as an Indonesian artist. He embraced an Indonesian identity while serving in a propaganda unit during the Revolution, and even more deeply during his subsequent pursuit of secondary education in Medan (1950-1955) and formal art training in Bandung (1955-1964). I think it would be wrong for us to say that he was stripped of Acehnese identity in adopting an Indonesian one. As James T. Siegel (2000:366) reminds us, there was for the longest time "no contradiction between being Acehnese and being Indonesian'. Yet producing a distinctly 'Indonesian' art held little interest for Pirous until his first journey abroad, to New York, in 1969-1970. It was there that he became an im- 
passioned cultural nationalist in his work: Disturbed by the condescending and neglectful attitudes he encountered regarding modern painting from his country-indeed by the sheer absence of modern Indonesian art in the city's galleries-he felt a mix of emptiness, exclusion, and betrayal. An intense, brooding search for an Indonesian painterly identity followed.

It is in Pirous's search for a distinctive and subjectively intimate Indonesian cultural signature that we see variation on Hutchinson's observations about progressive cultural nationalism. It is very much the case that Pirous was and has been in colloquy with a trans-national secular culture since 1955 , principally through the globalized discourses of modernist and postmodernist art. But he also turned to the trans-national sphere of Islamic aesthetics, and in particular, an exploration of the Qur'anic/ Arabic calligraphic figure, which he saw as emblematic of his Acehnese cultural heritage, of Indonesian national culture, and the civilizational sweep of Islam. His cultural nationalism, then, is also in dialogue with a transnational religion, a possibility that Hutchinson does not acknowledge in his reflections on cultural nationalism.

Pirous worked through problems of hybridizing Islamic and modernist aesthetics over the course of the next twenty years (1970-1990). That exploration saw him making painterly allusions to Aceh from time to time, by using visual icons he associates with Acehnese material culture — embroidery, and inscribed gravestones in particular. But he sees such work as consistent with his broader effort at achieving an Indonesian painterly identity. Indeed, for him, Islam, Indonesia, and Aceh can be equated in cultural terms. It was Pirous's work on Festival Istiqlal-a 'festival of Indonesian culture inspired by Islam' - and the Al-Qur' an Mushaf Istiqlal in the early 1990's that we see an emergent multicultural nationalist. Indeed, it was in
1994 that I first heard Pirous use the terms 'multicultural' and 'multicultural Islam' as he described how mushaf border illuminationsdeveloped from regional folk designs - would iconically render tamaddun, Indonesian Islamic culture. Though I am not sure Pirous would agree with me, it is my view that the Indonesian multiculturalism he envisioned was not predicated so much on 'unity in diversity' as on a shared religious heritage inflected by a plurality of homogeneous local cultures. That is, he sees a transcendent spiritual commonality as permitting a politics of recognition and cooperativeness, as well as points of cultural connection, between bearers of different local cultures subsumed within the nation.

The cultural politics of the mushaf are complicated; I have discussed them in depth elsewhere (George 1998) and so will touch on them but briefly here in light of my remarks on multiculturalism. The aestheticization, folklorization, and de-politicization of cultural 'traits' were as key to mushaf design work as were the carefully inscribed and rigorously examined Qur'anic sura. At the same time, the favor given to designs derived from 'Melayu' culture regions - and from Aceh in particularwas a calculated effort to call into question Javanese hegemony within the Indonesian nation-state and its cultural artifacts. An undoubted marvel of vision and artfulness, the national mushaf nonetheless leaves the nonMuslim a cultural blank, an unadmitted alterity. In short, the mushaf project was unable to evade hierarchies of cultural inclusion and exclusion, even while it placed a powerful claim on Indonesia's cultural past and future. It offered a qualified multiculturalism pegged to a majoritarian religion.

There is no question that the mushaf project was very much a product of the late Suharto years, a time when the regime was courting support from diverse precincts of the 
Muslim ummat. Adulation of the divine and acclaim for the national are entwined in this cultural artifact, and so link a transcendent spiritual-cultural commonality-Islam - to a transcendent political structure-the nation-state. If this is so, the mushaf also suggests the limits of cultural and political experiment: Creativity is possible so long as it does not transgress the Qur' anic message and Qur' anic culture; and there is no political autonomy for the constituent units of the nation-state. The multiculturalism of the mushaf is one of aesthetic differences, differences derived from a single, commonly held religious foundation (or discourse of truth) and which contribute to the glory of a single superordinate polity (the nation-state).

\section{Unsure calligraphy}

Pirous himself ran up against the communal limits of creative experiment earlier in his career. Strongly drawn to abstraction, and increasingly mindful of normative directions in Islamic aesthetics, he abandoned human figuration for explorations in calligraphy. Working in the 1970's on what he today calls 'expressive calligraphy', Pirous included in his paintings illegible figures that resembled Arab calligraphy. With them, the artist hoped to evoke a cultural atmosphere of spiritual mystery and give play to painterly expressiveness. Yet such figures caused consternation in some precincts of the ummat and public complaint was made that Pirous was deforming sacred Qur'anic verse. Meanwhile, other of his works from the same period featured accurately rendered Qur'anic verse, but came under the scrutiny of self-appointed scripturalists (rather than the public authorities known as the lajnah pentashih).

Anxiety and self-doubt about Qur'anic precision is quite keen in Indonesia, and in Sumatra has led to a history of intense scrutiny of locally produced copies of the Qur'an.
So even while Arab and other Middle Eastern collectors, museums, and galleries heaped praise on Pirous's calligraphic paintings, the artist had to tread carefully so as not to breach local boundaries of the permissible. At the same time, Pirous has always had to work in light of a popular fetishization of Arabic in which every instance of Arabic writing is construed as sacral, or as the Qur'an itself. This fetishization appears to cut across the nation's multicultural landscape. As one Indonesian wag commented to me not long ago, 'If an Indonesian buys a fish wrapped in a Jordanian newspaper, the paper will be carefully folded and kept on top of the family cabinet.' Such attitudes perhaps assure that Pirous's calligraphic paintings will be greeted with some reverence, but also place these artworks at risk of public scrutiny for scriptural improprieties.

A public artwork like the Al-Qur' an Mushaf Istiqlal required of Pirous and his design team unflagging precision and perfectionism. The approach of Pirous's career retrospective show in March 2002 put related anxieties and concerns at play once again. Beginning in February, Qur' anic experts on Pirous's curatorial team (Idris Pirous and Ilham Khoiri) examined all of Pirous's Qur' anic paintings still in his possession. They discovered a number of calligraphic errors, alas, mostly at the last minute, on the eve of the exhibit's opening on March $11^{\text {th }}$. Taking up a penknife, brushes, and paints, Pirous altered more than a dozen paintingssome dating back over a decade. Meanwhile, my suggestion for a promotional calligraphic T-shirt was turned down by members of the curatorial team owing to their worries that someone might take offense were a person to wear the shirt into restrooms. We also struggled over how to render Qur' anic Arabic in Roman orthography in a dual language artist's biography that I co-authored. As Pirous and Ilham remarked in discussion with me at the time, the 
Indonesian Muslim ummat consists of literalists who insist on standards for correct and precise transcriptive renderings of Qur'anic verse; moderates who forgive or don't even perceive errors; and liberals who put emphasis on the Qur'anic message, not its recitation or scriptural reproduction. Their remark tacitly admits that Qur' anic culture-which we might analytically distinguish from Muslim cultureis prone to conflict, debate, and a plurality of views. Their practical response? Acquiescence and concession to literalist hardliners and to those who fetishize Arabic orthography.

As Pirous prepared for his retrospective show, the Indonesian nation-state looked profoundly different than it did in 1995. Public disclosure of state-sponsored atrocities in Aceh, and the tenacity of Gerakan Aceh Merdeka in pressing their long held grievances, forced upon Pirous a split-subjectivity, where being Acehnese-Indonesian was no longer without problems and contradictions. A culture of violence has come to conjoin and mediate between the politically transcendent nation-state and one of its subordinate communities seeking autonomy. A culture of violence, too, warns Pirous, has also come to involve Islam as a transcendent discourse that could be used to mobilize the Acehnese against the Javanese hegemon that poses as the Indonesian nationstate and its military apparatus. Pirous has been unable to resolve this split in his artwork. 'Aceh' appears as a distinct cultural node in his body of work, but this time in opposition to-rather than in legitimation of - the nation-state. $\mathrm{Hu}-$ man figuration has made its return after a 30year absence in his paintings of bodies, limbs, and faces of the Acehnese dead. Are such paintings Acehnese paintings, or are they Indonesian? Calligraphic paintings based on quotes from the Acehnese 'Hikayat Prang Sabil' (Chronicle of the Holy War) and rendered in Arabic orthography-are they an Indonesian nightmare or spur to separatist aspirations? Is his Qur'anic painting entitled, 'The Fate of a People is in their Own Hands', an admonition to the national government or to GAM? Both?

\section{Closing}

Split-subjectivity isn't necessarily a bad thing, nor is debate about art in a diverse public sphere. My own feeling is that split-subjectivity is an inevitable effect of identity politics in a multicultural society. Identities are never singular or intrinsically stable, and neither are cultural communities - they are plural in their very constitution, and so are shaped as much by contradiction, irony, and change as they are by commonalities. Multiculturalism, for me, is a matter of taking this plurality and instability public, and not the gathering of categorically singular, static, and homogeneous cultures and cultural identities under state management. 'The belief in unique categorization,' writes Amartya Sen (2002:30), 'is both a serious descriptive mistake and an ethical and political hazard.' Such belief is often behind the univocal discourse of the nation-state or a religion as it trumps or silences the varied aspirations and needs of a diverse public. Seldom do we see the nation-state cease its demand for full ideological allegiance from its constituent collectivities, and seldom do we see the institutions of religion relax their efforts in policing definitions of 'their' community.

I think we see in Pirous's work over the decades the powerful effects of Indonesian nationalism and Islamic faith. I want to make clear that I don't at all fault him for embracing an Indonesian or Muslim identity, nor for harnessing these to his creative work; he has made enormous strides in pioneering vibrant forms of contemporary art with them. All the same, the broader cultural politics of Indonesian nationalism and Islam have placed before him creative limits and barriers, and have led him to 
see Indonesian and Islamic multiculturalism in problematic ways. His brilliant success within the precincts of conformism comes at the cost of anxious self-censorship vis-à-vis certain collectivities within the ummat. The same was true of his work vis-à-vis the nation during the Suharto years. But his anguish over the trag- edy in Aceh has, since 1998, given his work new purchase on the contradictions and uneasy pluralities hidden by the univocal cultural discourses of the state. In such work, I find hopeful prospects for shedding cultural nationalism and diversifying the nation's public sphere.

\section{References}

Chatterjee, $\mathrm{P}$.

1993 The Nation and Its Fragments: Colonial and Postcolonial Histories. Princeton: Princeton University Press.

Das, V.

1995 Critical Events: An Anthropological Perspective on Contemporary India. New Dehli: Oxford University Press.

George, K.M.

1998 'Designs on Indonesia's Muslim Communities', Journal of Asian Studies 57(3):693713.

Hutchinson, J.

1994 'Cultural Nationalism and Moral Regeneration', in J. Hutchinson and A.D. Smith (eds) Nationalism. Oxford: Oxford University Press. Pp.122-131.

Sen, A.

2002 'Civilizational Imprisonments', The New Republic June 10:28-33.

Siegel, J.T.

2000 The Rope of God. Revised edition. Ann Arbor: University of Michigan Press.

Turner, $\mathrm{T}$.

1993 'Anthropology and Multiculturalism: What is Anthropology that Multiculturalists Should be Mindful of It?', Cultural Anthropology 8(4):411-429. 